\title{
Physicochemical characteristics of gamma irradiation crosslinked poly(vinyl alcohol)/magnetite ferrogel composite
}

\author{
Milena T. Marinović-Cincović, Aleksandra N. Radosavljević, Jelena I. Krstić, Jelena P. Spasojević, \\ Nataša M. Bibić, Miodrag N. Mitrić, Zorica M. Kačarević-Popović
}

Vinča Institute of Nuclear Sciences, University of Belgrade, Belgrade, Serbia

\begin{abstract}
Magnetic field sensitive gels, ferrogels, are new promising class of hydrogels. The coupling of hydrogels and magnetic particles has potential application in soft actuators, such as artificial muscles, or for hyperthermia application. In this study, the composite of magnetite particles $\left(\mathrm{Fe}_{3} \mathrm{O}_{4}\right)$ and poly(vinyl alcohol) (PVA) hydrogel is developed using gamma irradiation as a crosslinking agent. PVA and $\mathrm{Fe}_{3} \mathrm{O}_{4}$ were chosen due to their well-established biocompatibility, radiation crosslinking potential (PVA), mild magnetic properties and the Curie point near desired heating temperature range $\left(\mathrm{Fe}_{3} \mathrm{O}_{4}\right)$. Physicochemical characteristics of these systems show the effect of the presence of particles in the process of radiation-induced crosslinking. Obtained $\mathrm{PVA} / \mathrm{Fe}_{3} \mathrm{O}_{4}$ ferrogel composite has greater swelling capacity, activation energy of dehydration and dehydration rate compared to PVA hydrogel, crosslinked under the same conditions.
\end{abstract}

Keywords: gamma irradiation, PVA hydrogel, magnetite particles, ferrogel, swelling properties, dehydration properties.

\section{Polymers}

SCIENTIFIC PAPER

UDC 544.773.43:66:53

Hem. Ind. 68 (6) 743-753 (2014)

doi: 10.2298/HEMIND141104081M
One of the goals of material research is to create new materials with properties tailored to a particular application and to understand the physical and chemical mechanisms that determine these properties. Hydrogels are crosslinked polymeric networks that are capable of imbibing water and swelling. New promising class of these materials is ferrogel, the magnetic field sensitive gel. Zrinyi at al. developed magnetic field sensitive gels in which magnetic particles of colloidal size are dispersed and incorporated into the gels [1]. These ferrogels combine the magnetic properties of magnetic fillers and the elastic properties of gels. When the gels were placed into a spatially non-uniform magnetic field, forces act on the magnetic particles and as result of strong interaction between magnetic particles and polymer chains, they all move together as a single unit. The coupling of hydrogels and magnetic particles has potential application in soft actuators such as artificial muscles [2]. On the other hand, the use of magnetic sensitive hydrogels has been recently explored for hyperthermia applications. The polymer networks have properties which make the hydrogels suitable for applications in controlled drug delivery systems, while the magnetic particles, with ferromagnetic or superparamagnetic properties are used for magnetic hyperthermia [3].

Correspondence: Z. Kačarević-Popović, Vinča Institute of Nuclear Sciences, University of Belgrade, P.O. Box 522, 11001 Belgrade, Serbia.

E-mail: zkacar@vinca.rs

Paper received: 4 November, 2014

Paper accepted: 17 November, 2014
The purpose of this work was to develop magnetically responsive polymer network based on composites of magnetic particles and hydrogels using gamma irradiation as a crosslinking agent, and to investigate its physico-chemical characteristics, such as swelling behavior and kinetics of dehydration of equilibrium swollen ferrogel.

The feasibility of this idea was explored by using poly(vinyl alcohol) ferrogel system $\left(\mathrm{PVA} / \mathrm{Fe}_{3} \mathrm{O}_{4}\right)$. PVA and $\mathrm{Fe}_{3} \mathrm{O}_{4}$ were chosen due to their well-established biocompatibility and history of clinical usage. Iron oxide is chemically stable, non-toxic and non-carcinogenic with mild magnetic properties and the Curie point near desired heating temperature range [3].

Moreover, PVA as a matrix component is selected because it is radiation crosslinking type polymer.

Mechanism of radiation chemical crosslinking is as follow:

a) When dilute aqueous solution of polymer is subjected to gamma irradiation, most of the energy of ionizing radiation is absorbed by water. As a result, short-lived reactive species are formed, mainly hydrated electrons $\left(\mathrm{e}_{\mathrm{aq}}^{-}\right)$, hydroxyl radicals $\left(\mathrm{OH}^{\circ}\right)$ and hydrogen atoms $\left(\mathrm{H}^{\circ}\right)$ :

$\mathrm{H}_{2} \mathrm{O} \stackrel{\gamma \text {-Irradiation }}{\longrightarrow} \mathrm{e}_{\mathrm{aq}}^{-}, \mathrm{OH}^{\bullet}, \mathrm{H}^{\bullet}, \mathrm{H}_{3} \mathrm{O}^{+}, \mathrm{H}_{2}, \mathrm{H}_{2} \mathrm{O}_{2}$

Out of these, hydroxyl radicals and hydrogen atoms are of interest in the present context, since they are capable to generate polymer radicals.

b) Both species $\left(\mathrm{OH}^{\circ}\right.$ and $\left.\mathrm{H}^{\circ}\right)$ abstract preferentially hydrogen atoms in $\alpha$-position to the hydroxyl group $(-\mathrm{CH}(\mathrm{OH})-)$ forming the tertiary radical $(\sim 70 \%)$, but 
also from methylene group $\left(-\mathrm{CH}_{2}-\right)$ forming secondary radical ( $30 \%)$, Scheme 1 , paths a and $b$, respectively. The $\mathrm{C}-\mathrm{H}$ bond dissociation energy of the secondary hydrogen is somewhat higher than that of the tertiary hydrogen and thus the some secondary radicals undergo the $\mathrm{H}$-abstraction reaction (Scheme 1, path $\mathrm{c}$ ) $[4,5]$.

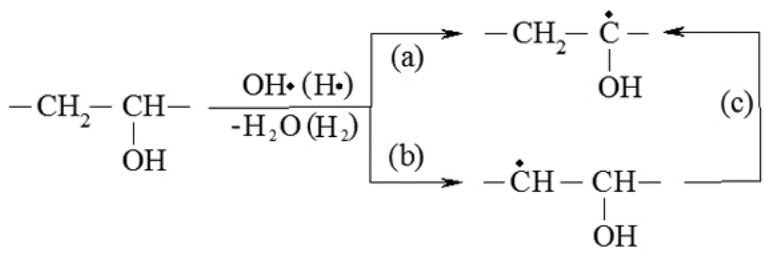

Scheme 1. Possible reaction pathways.

c) These PVA radicals may interact with one another by recombination, disproportionation, and chain scission (by $\beta$-fragmentation) [6]. In the case of PVA, the degradation cannot be totally avoided, but its yield is low and formation of polymer network occurs without any difficulty.

To construct three-dimensional polymer networks, the radiation chemistry method is offering advantages over conventional physical or chemical methods of network formation: mild reaction conditions, negligible formation of by-products, fast gelation, no need for catalysts and finally sterilization. Physicochemical properties of the radiation-crosslinked polymer network and the swelling ability of radiation-crosslinked hydrogels can be easily tailored by changing the irradiation time.

Preparation of ferrogels is similar to that of other filled elastomeric networks. One can precipitate welldispersed particles in the polymeric material. In situ precipitation can be made before, during or after the crosslinking reaction. According to another method, the preparation and characterization of colloidal particles is made separately from the crosslinking reaction. In this paper, we report preparation of later type.

\section{EXPERIMENTAL}

\section{Materials}

All chemicals were of analytical grade and used as received, without further purification. Poly(vinyl alcohol) (PVA) with molecular weight 72000 and min. 99\% degree of hydrolysis, and perchloric acid $\left(\mathrm{HClO}_{4}\right)$ were purchased from Merck. Iron(II) chloride $\left(\mathrm{FeCl}_{2}\right)$ and iron(III) chloride hexahydrate $\left(\mathrm{FeCl}_{3} \cdot 6 \mathrm{H}_{2} \mathrm{O}\right)$ were products of Sigma Aldrich and Polskie Odczynniki Chemiczne S.A., respectively. Deionized water was obtained from a Millipore Milli-Q system and used for solutions preparation and swelling experiments. High purity argon gas (99.5\%) was used for bubbling of solutions.

\section{Synthesis of $\mathrm{PVA} / \mathrm{Fe}_{3} \mathrm{O}_{4}$ ferrogel composite}

Iron oxide dispersion was prepared using the method already described, based on the coprecipitation of $\mathrm{FeCl}_{2}$ and $\mathrm{FeCl}_{3}$ by adding a concentrated solution of base into the mixture of iron salts [1]. The overall reaction can be written as:

$\mathrm{Fe}^{2+}+2 \mathrm{Fe}^{3+}+8 \mathrm{OH}^{-} \rightarrow \mathrm{Fe}_{3} \mathrm{O}_{4}+4 \mathrm{H}_{2} \mathrm{O}$

Obtained ferrofluid was black, which is the characteristic color of the magnetite. In order to counterbalance the Van der Waals attraction and the attractive part of magnetic dipole interactions, additional repulsion between the grains was achieved by electrostatic repulsion due to peptization (with $\mathrm{HClO}_{4}$ ).

The 5 wt\% PVA aqueous solution was prepared by dissolving polymer at $80{ }^{\circ} \mathrm{C}$ under the stirring for $6 \mathrm{~h}$ and then magnetic particles $\left(20\right.$ wt.\% $\mathrm{Fe}_{3} \mathrm{O}_{4}$ with respect to PVA) were added, and the solution was under the ultrasonication for $3 \mathrm{~h}$. Although it is known that polymer chains can be broken under the influence of ultra sound, irreversible aggregation as one of the major concerns during the preparation of magnetic ferrofluid cannot be avoided or resolved with standard mixing or homogenization. Therefore, the sonication method becomes the preferred choice to overcome the attractive forces holding the clumped particles together and to break apart irreversible aggregates that have formed. Both, the PVA solution and PVA $/ \mathrm{Fe}_{3} \mathrm{O}_{4}$ dispersion were aerated for 30 min with argon, in order to remove oxygen, and placed between two glass plates sealed with PVC spacer. The gamma irradiation was performed at ${ }^{60} \mathrm{Co}$ radiation source, under ambient condition, at a dose rate of $0.5 \mathrm{kGy} / \mathrm{h}$, to absorbed dose of $25 \mathrm{kGy}$ (our previous results confirmed that this is optimal irradiation dose for crosslinking [7]). The obtained ferrogels were immersed in deionized water, which was change every day, for one week, to remove uncrosslinked PVA, and dried at room temperature to constant mass. The masses of uncrosslinked PVA which were extracted from the PVA and PVA/magnetite composite hydrogel samples after crosslinking were 0.0021 and $0.0063 \mathrm{~g}$, respectively. In relation to the initial mass of PVA sample before extraction, or PVA in $\mathrm{PVA} / \mathrm{Fe}_{3} \mathrm{O}_{4}$ before extraction, it gives approximately $0.117(11.8 \%)$ and $0.348(34.8 \%)$ of sol fraction.

\section{Structural characterization}

The morphology of the as-prepared magnetite particles $\left(\mathrm{Fe}_{3} \mathrm{O}_{4}\right)$ was examined by transmission electron microscopy (TEM) using Philips EM 400 microscope operated at an accelerating voltage of $120 \mathrm{kV}$. Samples for TEM studies were prepared by placing a drop of the dispersion of $\mathrm{Fe}_{3} \mathrm{O}_{4}$ particles onto a carbon-coated copper grid, followed by evaporating the solvent at room temperature. Moreover, the morphology of 
$\mathrm{PVA} / \mathrm{Fe}_{3} \mathrm{O}_{4}$ xerogel composite surface was observed by scanning electron microscopy (SEM) using JEOL JSM-6460 LV microscope operated at an accelerating voltage of $25 \mathrm{kV}$. Before observation, the sample of xerogel was coated with carbon.

The X-ray diffraction (XRD) analysis of investigated $\mathrm{PVA} / \mathrm{Fe}_{3} \mathrm{O}_{4}$ xerogel composite was performed on Bruker D8 Advance diffractometer (CuK $\alpha 1$ radiation, $\lambda=$ $=0.1546 \mathrm{~nm}$ ).

FTIR spectra of xerogels, PVA and PVA/ $/ \mathrm{Fe}_{3} \mathrm{O}_{4}$ composite, were recorded using Thermo Electron Corporation Nicolet 380 FTIR spectrophotometer, with the addition for work in the attenuated total reflection (ATR) mode.

\section{Swelling experiments}

Dynamic swelling experiments were performed in deionized water at $37 \pm 0.2{ }^{\circ} \mathrm{C}$. Swollen gels, removed from the water at regular intervals, were dried superficially with filter paper, weighed and placed in the same bath. The swelling degree $(S D)$ was calculated using the following equation:

$S D=100\left(m_{t}-m_{0}\right) / m_{0}$

where $m_{0}$ and $m_{t}$ are the weights of the dry hydrogel (xerogel) at initial time $(t=0)$ and of the swollen hydrogel at time $t$, respectively.

The amount of absorbed water was measured until a constant weight of swollen hydrogel was reached $\left(m_{\text {eq }}\right)$. Substituting the $m_{t}$ by $m_{\text {eq }}$ in Eq. (4), the equilibrium swelling degree $\left(S D_{\text {eq }}\right)$ was calculated [8]. All swelling experiments were performed in triplicate and the average values were reported.

The normalized swelling degree $(\alpha)$ was defined as the ratio between the swelling degree at time $t\left(S D_{t}\right)$ and equilibrium swelling degree:

$\alpha=S D_{t} / S D_{\text {eq }}$

\section{Dehydration and thermal stability}

Dehydration of PVA hydrogel and PVA/ $\mathrm{Fe}_{3} \mathrm{O}_{4}$ ferrogel composite, were analyzed by thermogravimetric method. Thermogravimetric curves were recorded by a
Setaram's SETSYS Evolution 1750 thermogravimetry analyzer. Dehydration analyses were performed with $20 \pm 0.1 \mathrm{mg}$ of equilibrium swollen hydrogel, in platinum pans, under argon atmosphere (flow rate $16 \mathrm{~mL} / \mathrm{min}$ ). Measurements were carried out at heating rates $(\beta)$ of $2.5,5,10$ and $20^{\circ} \mathrm{C} / \mathrm{min}$ in the temperature range from 25 to $250{ }^{\circ} \mathrm{C}$. Moreover, the thermal stability of xerogels was investigated in the temperature range from 25 to $750{ }^{\circ} \mathrm{C}$, under the argon atmosphere at heating rate of $10^{\circ} \mathrm{C} / \mathrm{min}$.

\section{RESULTS AND DISCUSSION}

\section{Morphology and structural characterization}

The typical TEM micrograph of as-prepared magnetite particles is shown in Fig. 1. It can be seen that the most part of $\mathrm{Fe}_{3} \mathrm{O}_{4}$ particles have spherical shape, with the size up to about $20 \mathrm{~nm}$. Also, it can be observed that particles tend to aggregate into larger agglomerates, probably due to their extremely small sizes, high surface energies and magnetic properties.

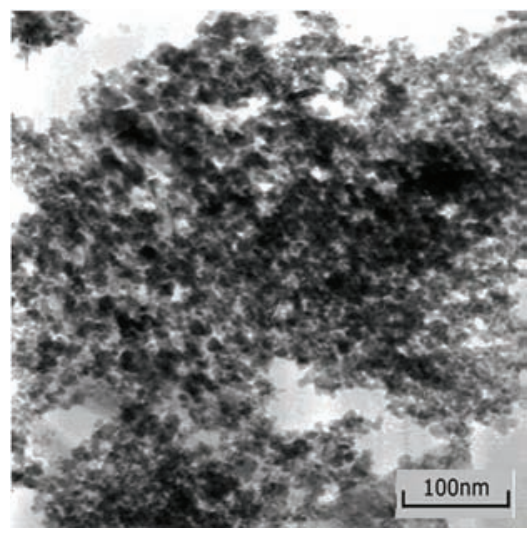

Fig. 1. TEM Micrograph of as-prepared magnetite particles.

In an attempt to explore the composite morphology, SEM micrographs were obtained. Figure 2 corresponds to $\mathrm{PVA} / \mathrm{Fe}_{3} \mathrm{O}_{4}$ xerogel composite surface. It can be seen that the magnetic particles agglomerate, probably due to reduced stabilization ability of polymer network on the surface, as well as due to heating of
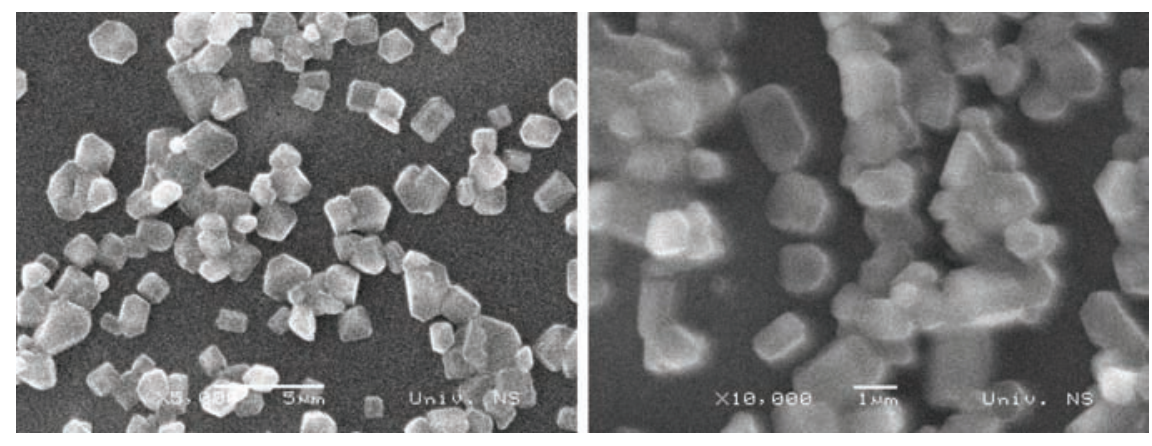

Fig. 2. SEM Micrographs of $\mathrm{PVA} / \mathrm{Fe}_{3} \mathrm{O}_{4}$ xerogel composite surface. 
system in consequence of energy absorption during gamma irradiation. Formed agglomerates have different shape and size in the range up to about $2 \mu \mathrm{m}$.

XRD technique was used to identify the desired particles prepared with ferric and ferrous salts, over $2 \theta$ range from 10 to $70^{\circ}$. In general, particles can be crystalline, amorphous or quasi-crystalline [9].

Crystalline magnetite structure is an inverse spinel with a face center cubic unit based on $32 \mathrm{O}^{2-}$ ions. There are eight formula units per unit cell. Magnetite differs from other iron oxides in that it contains both divalent and trivalent iron. Its formula is written as $\mathrm{Fe}^{\text {III }}\left[\mathrm{Fe}^{\mathrm{II}} \mathrm{Fe}^{\mathrm{III}}\right] \mathrm{O}_{4}$ and the brackets denote octahedral sites. Tetrahedral Fe spins are directed antiparallel to octahedral $\mathrm{Fe}^{3+}$ and $\mathrm{Fe}^{2+}$ spins, so that the $\mathrm{Fe}^{3+}$ moments cancel, leaving a spontaneous magnetization equivalent to one $\mathrm{Fe}^{2+}$ moment per molecule. Eight tetrahedral sites are occupied by trivalent iron, and the divalent and trivalent cations occupied the sixteen octahedral sites. Although, X-ray diffraction is the most widely used technique to determine the crystalline structure of a material, in the case of magnetite it can be confusing because the magnetite has the same crystalline structure as maghemite, but this one has a interstitial voids, therefore by using XRD is not conclusive [10]. The diffraction peaks (Fig. 3) corresponding (220), (400) and (511) are characteristic peaks of the $\mathrm{Fe}_{3} \mathrm{O}_{4}$ crystal. Diffraction peaks corresponding to (024) and (300) are characteristic peaks of $\alpha-\mathrm{Fe}_{2} \mathrm{O}_{3}$. The obtained XRD pattern suggests that the final product was a mixture of $\mathrm{Fe}_{3} \mathrm{O}_{4}$ and $\alpha-\mathrm{Fe}_{2} \mathrm{O}_{3}$. The existence of $\alpha-\mathrm{Fe}_{2} \mathrm{O}_{3}$ is common and occurs because of the oxidation of $\mathrm{Fe}_{3} \mathrm{O}_{4}$ during synthesis. In this case it is probably caused due to the heating of system in consequence of energy absorption during gamma irradiation.

Moreover, in the case of magnetite, the infrared spectroscopy is useful because this technique arises as a result of divalent and trivalent cations interaction with electromagnetic radiation. This interaction involves excitation for vibration or rotation of molecules in their ground electronic state, and they are associated with stretching deformation of the interatomic bonds and bending deformation of the interbond angles. In general, infrared spectra of the magnetite show the characteristic bands at $590 \mathrm{~cm}^{-1}$ due to the $\mathrm{Fe}-\mathrm{O}$ bond. It was observed that this characteristic absorption band of bulk $\mathrm{Fe}_{3} \mathrm{O}_{4}$ was shifted from 573 to $656 \mathrm{~cm}^{-1}$ in the case of particles. It is caused by the breaking of a large number of bonds of surface atoms, resulting in the rearrangement of unlocalized electrons on the particle surface. In general the band at $600 \mathrm{~cm}^{-1}$ approximately is broadening when the particle size decreases. The existence of this characteristic absorption band, as shown in Fig. 4, confirms the presence of spinel structure $\mathrm{Fe}_{3} \mathrm{O}_{4}$ [11]. In addition, the peak at $1594 \mathrm{~cm}^{-1}$ observed in xerogel of $\mathrm{PVA} / \mathrm{Fe}_{3} \mathrm{O}_{4}$ composite curve probably indicates a complex interaction between hydroxyl groups and oxygen containing groups emerged during sonication, on the surface of magnetic particles [12]. Since there are large surface-to-volume atomic ratio, the high surface activity and amount of dangling bonds on nanoparticle surface, the atoms on the surface are apt to adsorb ions or molecules. For $\mathrm{Fe}_{3} \mathrm{O}_{4}$ particles dispersed in a PVA xerogel, the atoms of $\mathrm{Fe}$ and $\mathrm{O}$ on the particle surface would adsorb $\mathrm{OH}$ groups and oxygen containing groups (carbonyl or carboxyl) causing their hydrogen bonding and a red shift of aliphatic oxygen groups adsorption from $1680-1750 \mathrm{~cm}^{-1}$ to $1594 \mathrm{~cm}^{-1}$.

\section{Swelling studies}

When a xerogel is brought into contact with water, the water diffuses into the network and volume phase transition occurs, resulting in the expansion of the hydrogel, e.g., hydrogel swells. Diffusion involves the migration of water into pre-existing or dynamically formed spaces among hydrogel chains. The capacity of

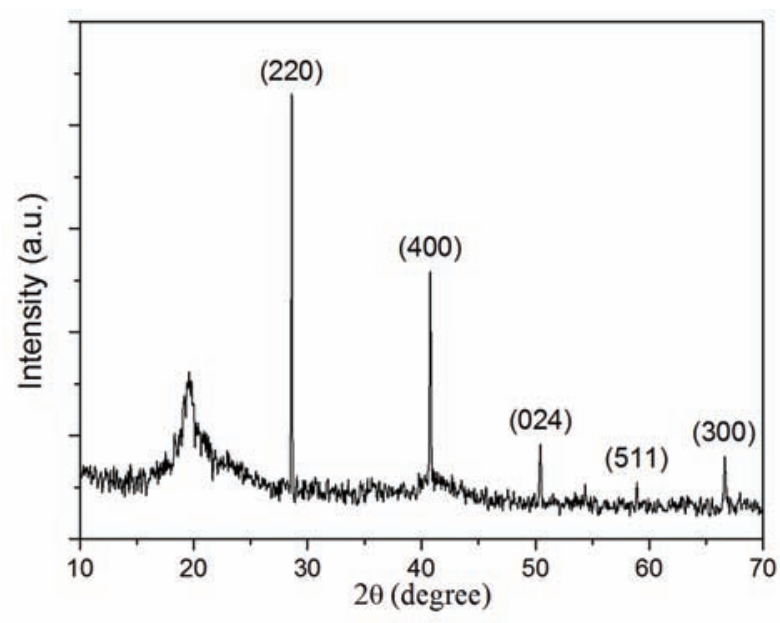

Fig. 3. XRD Pattern of the $\mathrm{PVA} / \mathrm{Fe}_{3} \mathrm{O}_{4}$ xerogel composite. 


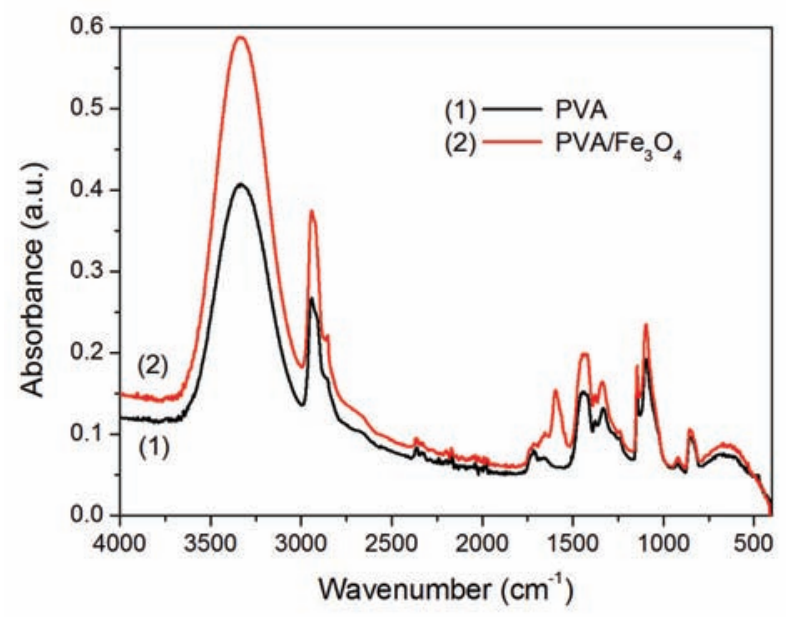

Fig. 4. FTIR Spectra of xerogels: PVA and $\mathrm{PVA} / \mathrm{Fe}_{3} \mathrm{O}_{4}$ composite.

swelling is one of the most important parameters for evaluation the physicochemical properties of hydrogels. Many structural factors (charge and concentration of ionizable groups, degree of ionization, crosslinking density and hydrophilicity) influence the swelling degree of hydrogels, and the properties of swelling medium (the $\mathrm{pH}$, ionic strength, counterion and its valence) affect the swelling characteristics [13].

PVA is hydrophilic polymer with a large number of hydrophilic - $\mathrm{OH}$ groups, which can easily form hydrogen bonds with free water molecules [14]. So, $\mathrm{H}_{2} \mathrm{O}$ and other small molecules, easily penetrate into the space between the PVA chains, giving swelled polymer network. Figure 5 depicts the swelling curves of the PVA hydrogel (control sample) and PVA $/ \mathrm{Fe}_{3} \mathrm{O}_{4}$ ferrogel composite in distilled water at $37{ }^{\circ} \mathrm{C}$. As can be seen from the presented results, the swelling isotherms are similar in shape, but crosslinking of PVA in the presence of $\mathrm{Fe}_{3} \mathrm{O}_{4}$ particles has significant influence on the swelling properties in comparison to pure PVA hydrogel.
Three characteristic regions may be distinguished in swelling curves presented in Fig. 5: a linear part, a nonlinear part and a saturation range or plateau. In order to analyze the influence of xerogel structure on the swelling isotherm shape, specific parameters of the swelling isotherms are defined: period of linearity, initial swelling rate and swelling equilibrium degree. The period of linearity e.g., range of applicability $(P)$ presents the region of the normalized swelling degree, within which the kinetic swelling curves are linear. The initial swelling rate $\left(v_{\text {in }}\right)$ is defined as the ratio of the swelling degree in the final point of the linear part of the swelling curve $\left(S D_{\text {in }}\right)$ to the swelling time that corresponds to the linear part of the swelling curve $\left(t_{\text {in }}\right)$ $[15,16]$ :

$v_{\text {in }}=S D_{\text {in }} / t_{\text {in }}$

Table 1 presents the changes of the equilibrium swelling degree $\left(S D_{\text {eq }}\right)$, the initial swelling rate $\left(v_{\text {in }}\right)$ and range of applicability $(P)$ for the PVA hydrogel and

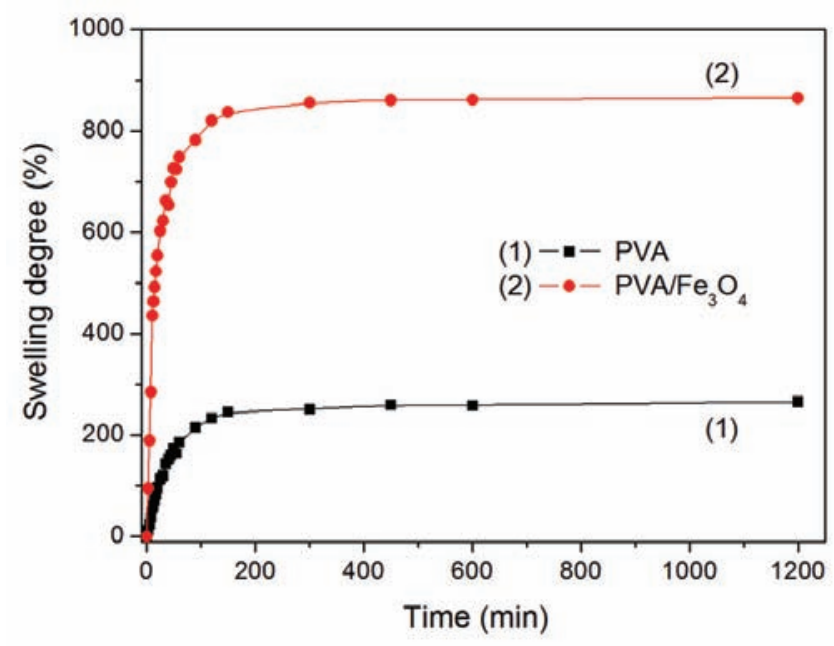

Fig. 5. Swelling isoterms of PVA hydrogel and $\mathrm{PVA} / \mathrm{Fe}_{3} \mathrm{O}_{4}$ ferrogel composite in distilled water at $37{ }^{\circ} \mathrm{C}$. 
$\mathrm{PVA} / \mathrm{Fe}_{3} \mathrm{O}_{4}$ ferrogel composite in distilled water at 37 ${ }^{\circ} \mathrm{C}$. The obtained values show that with incorporation of $\mathrm{Fe}_{3} \mathrm{O}_{4}$ particles in PVA hydrogel all specific parameters of the swelling isotherms are increased. The swelling capacity and initial swelling rate of $\mathrm{PVA} / \mathrm{Fe}_{3} \mathrm{O}_{4}$ ferrogel composite is found to be about 3.3 and 8.1 times, respectively, higher in comparison with control PVA hydrogel, which directly indicated that the crosslinking of PVA in the presence of $\mathrm{Fe}_{3} \mathrm{O}_{4}$ particles caused decreasing of crosslinking density. In general, it is well known that swelling is directly related to the structure of the crosslinked polymer and/or the density of the hydrogel.

Table 1. Specific parameters of swelling isotherms for PVA hydrogel and $\mathrm{PVA} / \mathrm{Fe}_{3} \mathrm{O}_{41}$

\begin{tabular}{lccc}
\hline Sample & $S D_{\text {eq }} / \%$ & $v_{\text {in }} / \% \mathrm{~min}^{-1}$ & $P / \%$ \\
\hline PVA & 261 & 4.1 & $0-55$ \\
PVA/Fe3O4 & 863 & 33.4 & $0-57$ \\
\hline
\end{tabular}

Swelling of the hydrogels involves large segmental motion, resulting ultimately in an increase in the separation distance among the hydrogel chains, and occurs until thermodynamic equilibrium was reached. The swelling equilibrium occurs when the values of the osmotic force driving the solvent into the network and when the elastic forces of the stretched sub-chains become equal. To analyze the model of water diffusion into the polymer network, the water sorption data was used. When the mass of water absorbed by the polymer, as a function of time $\left(M_{t}\right)$, is normalized to the mass of water absorbed by the polymer at its equilibrium hydration level $\left(M_{\infty}\right)$, the time-dependent swelling of the polymer was determined according to the following equation:

$M_{t} / M_{\infty}=k t^{n}$ where $k$ is a characteristic constant of the hydrogel, $t$ is time and $n$ is a characteristic exponent of the swelling (also noted as diffusion exponent) which represents solvent diffusion modes inside hydrogels, and provides information about the mechanism of swelling kinetics. The constants $n$ and $k$ can be calculated from a plot In $\left(M_{t} / M_{\infty}\right) v s$. In $t$, from the slope and intercept, respectively. This equation is applicable to the initial stages of swelling, where a linear fit of the data was observed $\left(M_{t} / M_{\infty} \leq 0.6\right)[17,18]$. The graphical representation of $\ln \left(M_{t} / M_{\infty}\right) v s$. In $t$ is shown in Fig. 6.

The characteristic constants $n$ and $k$ can be related to the specific transport mechanism. It is generally accepted that the diverse responses of hydrophilic polymer networks to the presence of water can be described with three models, based on the relative rates of diffusion and polymer chain relaxation: $i)$ Fickian or Case I diffusion ( $n \leq 0.5$ ), occurs when the rate of diffusion is significantly slower than the rate of the polymer chains relaxation; ii) Case II diffusion ( $n=$ $=1$ ) arises when the rate of diffusion is greater than the rate of the polymer chains relaxation. The main feature of this second limiting model is the establishment of a sharp boundary between the glassy core and the swollen shell, which advances at a constant velocity; iii) non-Fickian or anomalous diffusion $(0.5<n<1)$ occurs when the rates of diffusion and polymer chain relaxation are comparable, and is connected with the transition region between the two limiting cases of Case I and Case II $[19,20]$. The characteristic constants $n$ and $k$, calculated from parameters of straight line, Fig. 6, are given in Table 2. It is evident that in the case of considered condition (distilled water at $37{ }^{\circ} \mathrm{C}$ ), the diffusion is non-Fickian for PVA hydrogel ( $n=0.9050)$, as well as for $\mathrm{PVA} / \mathrm{Fe}_{3} \mathrm{O}_{4}$ ferrogel composite $(n=$ $=0.9117$ ). The obtained results unambiguously indicate that the transport of water molecules into the polymer

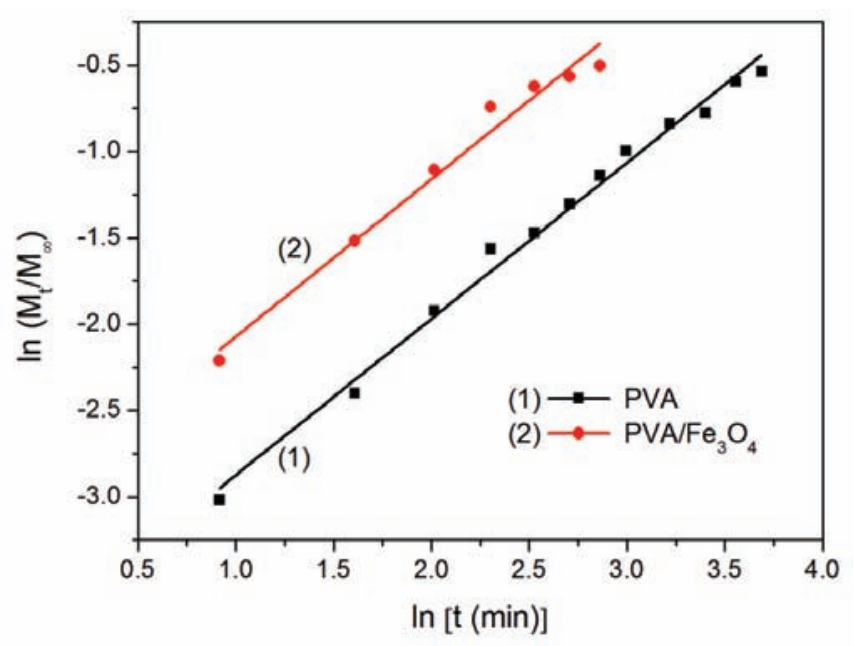

Fig. 6. The plots of In $\left(\mathrm{M}_{t} / \mathrm{M}_{\infty}\right)$ vs. In $t$ for PVA hydrogel and $\mathrm{PVA} / \mathrm{Fe}_{3} \mathrm{O}_{4}$ ferrogel composite in distilled water at $37{ }^{\circ} \mathrm{C}$. 
network is controlled by both diffusion and polymer chain relaxation.

Table 2. Swelling parameters $k$ and $n$, and correlation coefficients for PVA hydrogel and $\mathrm{PVA} / \mathrm{Fe}_{3} \mathrm{O}_{4}$ ferrogel composite in distilled water at $37^{\circ} \mathrm{C}$

\begin{tabular}{lccccc}
\hline Sample & $k$ & $n$ & $R^{2}$ & $\begin{array}{c}D E \times 10^{8} \\
\mathrm{~cm}^{2} / \mathrm{s}\end{array}$ & $\begin{array}{c}D L \times 10^{9} \\
\mathrm{~cm}^{2} / \mathrm{s}\end{array}$ \\
\hline PVA & 0.0229 & 0.9050 & 0.9904 & 1.02 & 2.27 \\
PVA $/ \mathrm{Fe}_{3} \mathrm{O}_{4}$ & 0.0506 & 0.9117 & 0.9757 & 2.65 & 3.17 \\
\hline
\end{tabular}

The initial swelling process exhibits a non-Fikian behavior, while the extensive swelling process follows the Schott kinetics:

$$
\mathrm{d} S D / \mathrm{d} t=k_{\mathrm{S}}\left(S D_{\text {eq }}-S D\right)^{2}
$$

A rearrangement of Eq. (8):

$$
t / S D=A+B t
$$

gives constants $A=1 / v_{0}\left(v_{0}=k_{S} S D_{\infty}{ }^{2}\right)$ and $B=1 / S D_{\infty}$ [19-21].

The Eq. (9) represents second order kinetics and a function relation of $t / S D$ versus $t$ gives the straight line (Fig. 7).

Equilibrium swelling (or as usually used, theoretical equilibrium swelling), initial rate of swelling and swelling rate constant for PVA hydrogel and $\mathrm{PVA} / \mathrm{Fe}_{3} \mathrm{O}_{4}$ ferrogel composite are calculated from the slope and intercept of the lines, and given in Table 3. The values of theoretical equilibrium swelling of the hydrogels are in good agreement with the experimentally obtained values (presented in Table 1). The swelling kinetic equations of PVA hydrogel and $\mathrm{PVA} / \mathrm{Fe}_{3} \mathrm{O}_{4}$ ferrogel composite are also presented in Table 3. All the $R^{2}$ are greater than 0.99, indicating a small estimated standard error and a highly precise linear regression equation. The obtained results indicate that swelling process of $\mathrm{PVA} / \mathrm{Fe}_{3} \mathrm{O}_{4}$ ferrogel composite is quicker than the swelling rate of PVA hydrogel (Table 3).

Table 3. Swelling kinetic equation, theoretical equilibrium swelling degree $\left(S D_{\infty}\right)$, swelling rate constant $\left(k_{S}\right)$ and initial swelling rate $\left(v_{0}\right)$ for $\mathrm{PVA}$ hydrogel and $\mathrm{PVA} / \mathrm{Fe}_{3} \mathrm{O}_{4}$ ferrogel

\begin{tabular}{|c|c|c|c|c|c|}
\hline Sample & $\begin{array}{l}\text { Swelling kinetic } \\
\text { equation } \\
\text { (Eq. (9)) }\end{array}$ & $R^{2}$ & $\begin{array}{c}\mathrm{SD}_{\infty} \\
\%\end{array}$ & $\begin{array}{c}v_{0} \\
\% / \min \end{array}$ & $\begin{array}{l}\mathrm{ks} \times 10^{4} \\
1 / \% \mathrm{~min}\end{array}$ \\
\hline PVA & $\begin{array}{c}t / S D=0.1288+ \\
\quad+0.0037 t\end{array}$ & 0.9988 & 273 & 7.76 & 1.04 \\
\hline $\mathrm{PVA} / \mathrm{Fe}_{3} \mathrm{O}_{4}$ & $\begin{array}{c}t / S D=0.0135+ \\
\quad+0.0011 t\end{array}$ & 0.9998 & 876 & 74.07 & 0.96 \\
\hline
\end{tabular}
composite in distilled water at $37{ }^{\circ} \mathrm{C}$

As already stated, the Eq. (7) represents the time-dependent swelling of the polymer network and can be related to the diffusion coefficient $[17,18]$. The early-time approximation method for calculating diffusion coefficients of water into the hydrogel, which is generally valid only for the first $60 \%$ of the swelling, is given as:

$M_{t} / M_{\infty}=4\left(D_{\mathrm{E}} t / \pi \delta\right)^{1 / 2}$

where $D_{\mathrm{E}}$ is the coefficient of water diffusion for the early stage of swelling, $t$ is the time and the $\delta$ is thickness of the xerogel. The diffusion coefficients were also calculated from the late-time approximation which is presented as:

$M_{t} / M_{\infty}=1-\left(8 / \pi^{2}\right) \exp \left(-\pi^{2} D_{\mathrm{L}} t / \delta^{2}\right)$

where $D_{\mathrm{L}}$ is the coefficient of water diffusion for the longer diffusion times.

The values of the coefficients of water diffusion for early- and late-time approximations are presented in Table 2. The value of the coefficient of diffusion

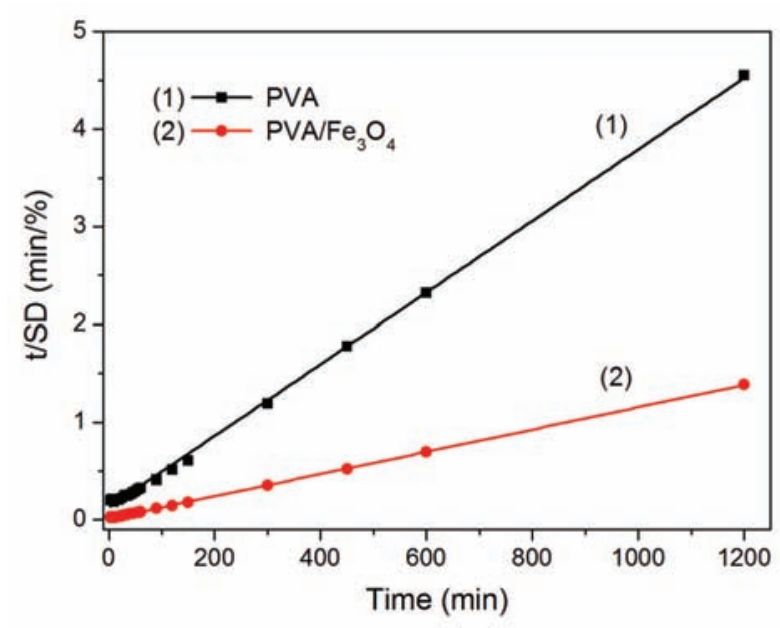

Fig. 7. The plots of $t / S D$ vs. $t$ for $P V A$ hydrogel and $\mathrm{PVA} / \mathrm{Fe}_{3} \mathrm{O}_{4}$ ferrogel composite in distilled water at $37{ }^{\circ} \mathrm{C}$. 
increases in the case when the crosslinking of PVA occurred in the presence of $\mathrm{Fe}_{3} \mathrm{O}_{4}$ particles, compared to control PVA hydrogel crosslinked under the same conditions. Also, it can be noticed, that the $D_{\mathrm{L}}$ is higher than the $D_{\mathrm{E}}$ value, as can be expected bearing in mind the higher water absorption values. According to the theory of Reinhart and Peppas [22] the large swelling ratios lead to higher coefficients of water diffusion.

\section{Kinetic of non-isothermal dehydration and thermal stability}

Beside the swelling capacity, another important physicochemical characteristic of hydrogels (and ferrogels), which may affect its usability in various applications, is dehydration. Conversion curves of dehydration of PVA hydrogel and PVA $/ \mathrm{Fe}_{3} \mathrm{O}_{4}$ ferrogel composite obtained at different heating rates $(2.5,5,10$ and 20 ${ }^{\circ} \mathrm{C} / \mathrm{min}$ ) are shown in Fig. 8.

All the curves are asymmetric and were moved to higher temperatures with increase of heating rate. From Fig. 8 it can be seen that for the same value of conversion (for example 50\%), at the same heating rate, the dehydration temperatures are higher for the PVA hydrogel in comparison with the $\mathrm{PVA} / \mathrm{Fe}_{3} \mathrm{O}_{4}$ ferrogel composite. The activation energy of dehydration was determined using the model-free kinetics method, which is based on calculation of the effective activation energy $\left(E_{\mathrm{a}}\right)$ as a function of the conversion $(\alpha)[23,24]$. The respective conversion curves are calculated out of the TG measured curves. For each conversion, the plot In $\left(\beta / T^{2}\right)$ versus $1 / T \alpha$ ( $\beta$ is the heating rate, $T$ is the temperature) giving rise to a straight line with slope $-E_{\mathrm{a}} \alpha / R$, therefore providing the activation energy as a function of conversion.

The activation energy for the thermal dehydration process of PVA hydrogel and the PVA $/ \mathrm{Fe}_{3} \mathrm{O}_{4}$ ferrogel composite is shown in Fig. 9. The standard deviation was in the range from 0.03 for PVA hydrogel to 0.09 to $\mathrm{PVA} / \mathrm{Fe}_{3} \mathrm{O}_{4}$ ferrogel composite. Note that the activation energy for pure PVA hydrogel is lower than that for the dehydration of $\mathrm{PVA} / \mathrm{Fe}_{3} \mathrm{O}_{4}$ ferrogel composite, which means that magnetite filler increases the energy barrier of the thermal dehydration process.

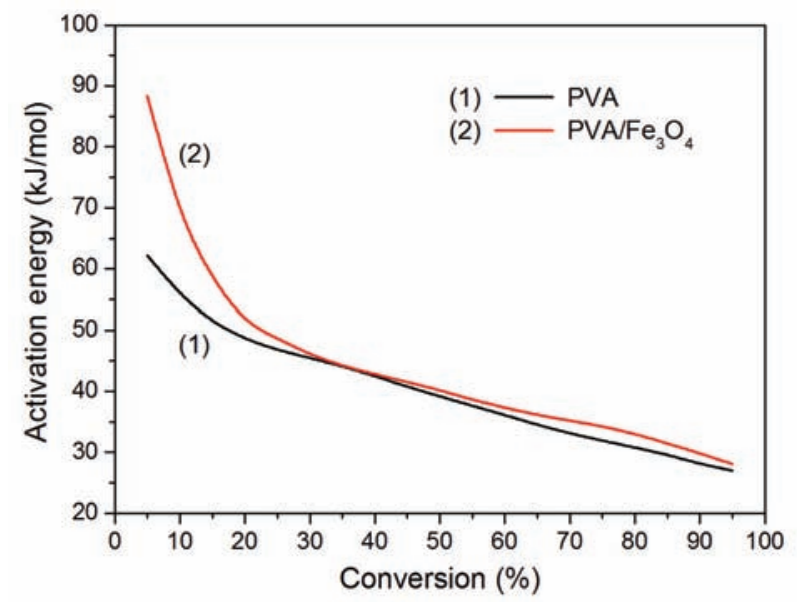

Fig. 9. Dependence of dehydration activation energy on conversion for PVA hydrogel and $\mathrm{PVA} / \mathrm{Fe}_{3} \mathrm{O}_{4}$ ferrogel composite under non-isothermal conditions.

The observation made from conversion curves in Fig. 8 is more evident when examining the plots of conversion versus time, as it is shown in Fig. 10 that was obtained from the model-free data. These graphs show comparative curves between PVA hydrogel and $\mathrm{PVA} / \mathrm{Fe}_{3} \mathrm{O}_{4}$ ferrogel composite at several set temperatures. One can see clearly that the time for the dehydration of PVA hydrogel and PVA $/ \mathrm{Fe}_{3} \mathrm{O}_{4}$ ferrogel composite decreases considerably as a function of temperature. The $\mathrm{PVA} / \mathrm{Fe}_{3} \mathrm{O}_{4}$ ferrogel composite dehydrates faster than pure PVA hydrogel at all temperatures and all heating rates, except for $10^{\circ} \mathrm{C} / \mathrm{min}$ (Fig. 10C).

Moreover, the thermal stability of the investigated xerogels was studied by thermogravimetry analysis and the obtained TGA curves are presented in Fig. 11. The

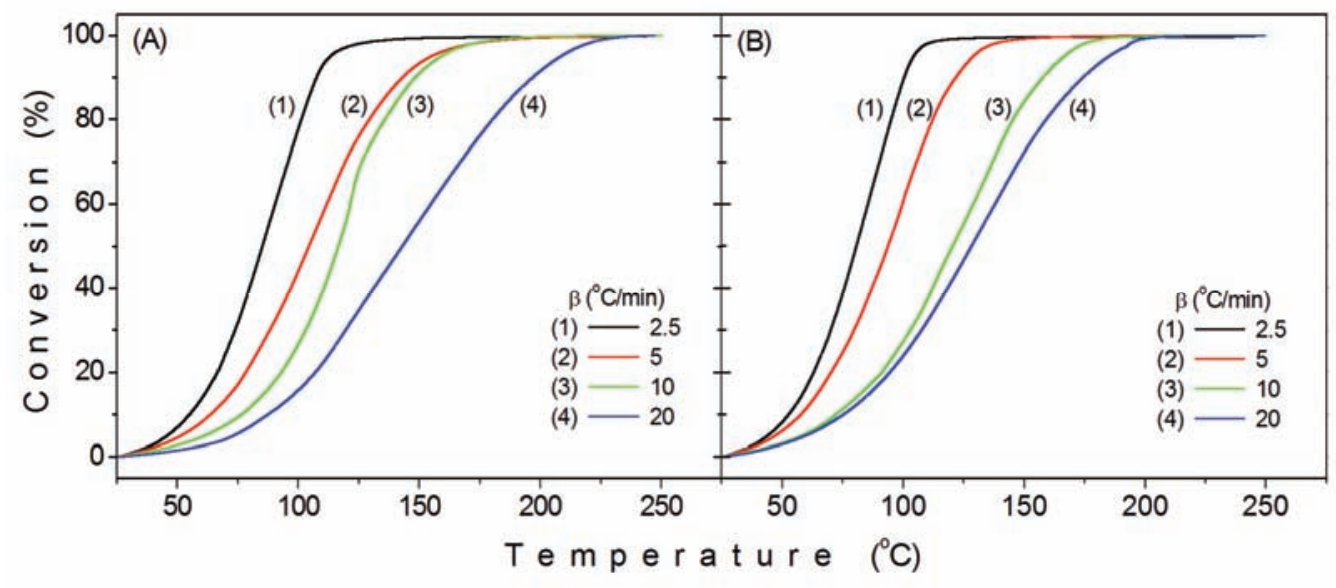

Fig. 8. Conversion curves of dehydration of PVA hydrogel (A) and $\mathrm{PVA} / \mathrm{Fe}_{3} \mathrm{O}_{4}$ ferrogel composite (B). 


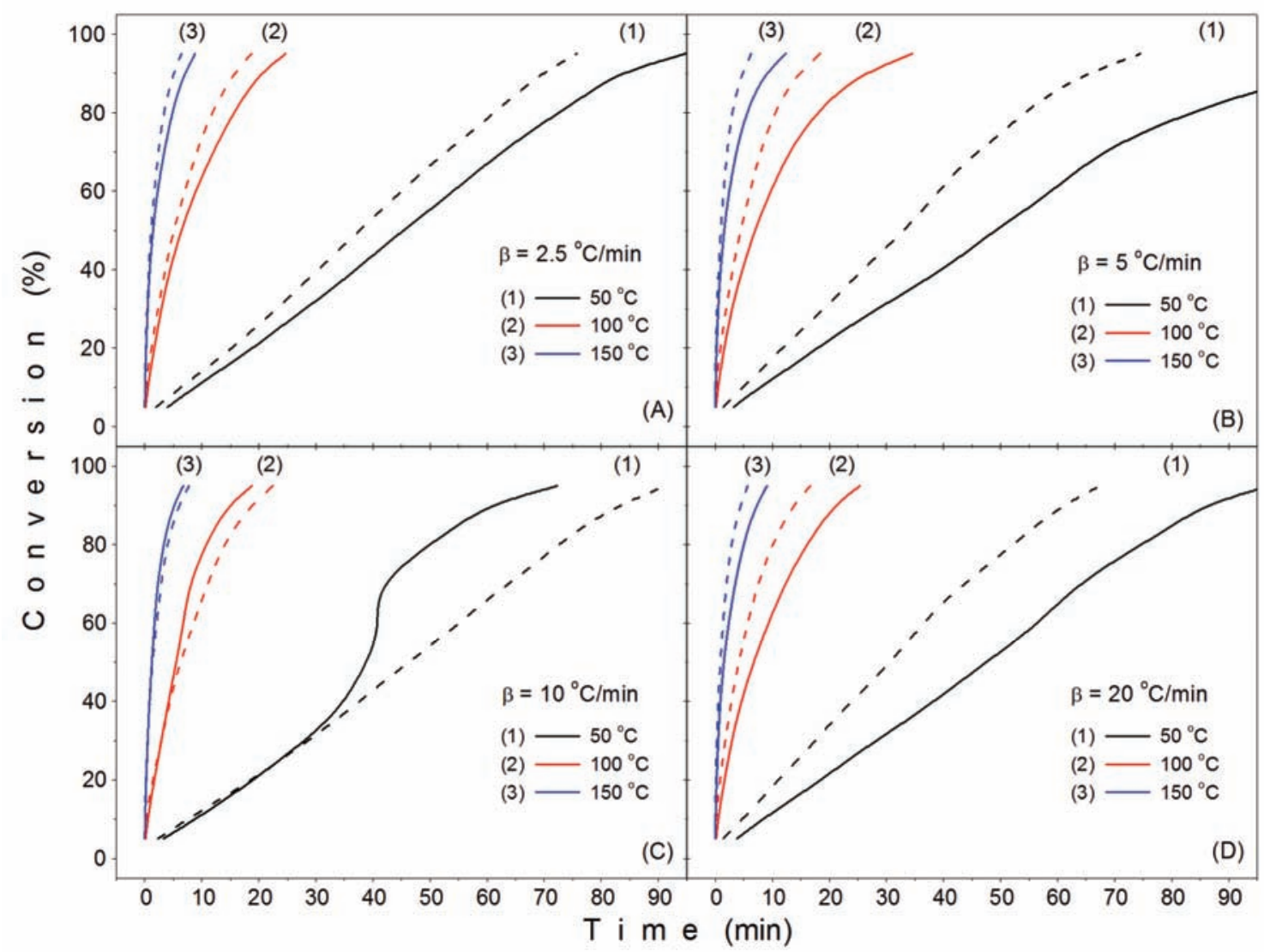

Fig. 10. Dehydration conversion of PVA hydrogel (solid line) and $\mathrm{PVA} / \mathrm{Fe}_{3} \mathrm{O}_{4}$ ferrogel composite (dashed line) as a function of time, for different heating rates.

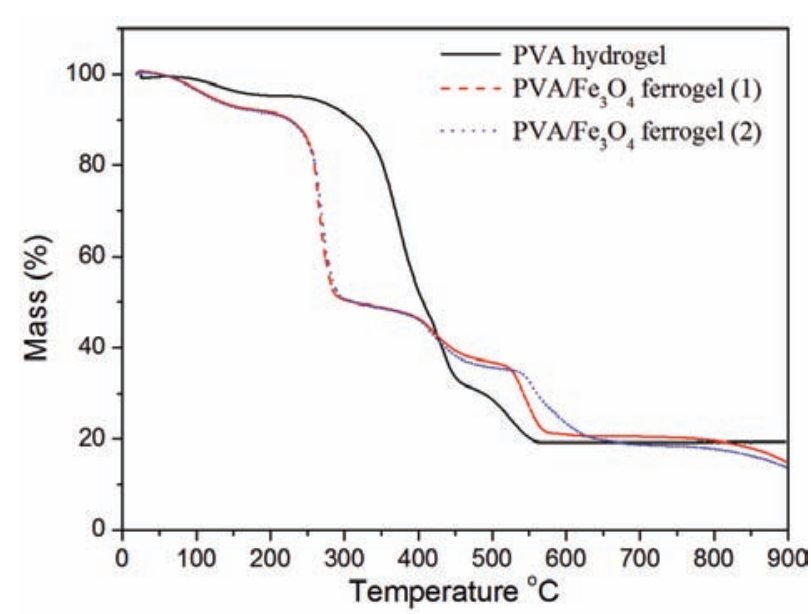

Fig. 11. TGA curves of PVA hydrogel and $\mathrm{PVA} / \mathrm{Fe}_{3} \mathrm{O}_{4}$ ferrogel composite.

TGA curve of $\mathrm{PVA} / \mathrm{Fe}_{3} \mathrm{O}_{4}$ xerogel composite exhibits a steeper slope between 100 and $450{ }^{\circ} \mathrm{C}$, indicating a lower thermal stability in comparison to the pure PVA xerogel. It is probably caused by the change of the network structure, mainly due to the decrease in the crosslink density.

\section{CONCLUSION}

This study shows that gamma irradiation crosslinking of polymer in the presence of particles does not interrupt processes of intra- and/or intermolecular crosslinking of PVA chains, giving $\mathrm{PVA} / \mathrm{Fe}_{3} \mathrm{O}_{4}$ ferrogel composite. Thus obtained crosslinked structure has an influence on the physicochemical characteristics of ferrogels. An increase in the values of swelling kinetic parameters, dehydration rate as well as the activation energy of dehydration is noticed for ferrogel compared to pure PVA hydrogel crosslinked under the same conditions.

\section{Acknowledgement}

This work is financed by the Ministry of Education, Science and Technological Development of the Republic of Serbia, projects III 45005 and 172056.

\section{REFERENCES}

[1] M. Zrínyi, L. Barsi, A. Büki, Ferrogel: a new magnetocontrolled elastic medium, Polym. Gels Netw. 5 (1997) 415-427. 
[2] R.V. Ramanujan, L.L. Lao, The mechanical behavior of smart magnet-hydrogel composites, Smart Mater. Struct. 15 (2006) 952-956.

[3] L.L. Lao, R.V. Ramanujan, Magnetic and hydrogel composite materials for hyperthermia applications, J. Mater. Sci. Mater. Med. 15 (2004) 1061-1064.

[4] B. Wang, S. Mukataka, E. Kokufuta, M. Kodama, The influence of polymer concentration on the radiationchemical yield of intermolecular crosslinking of poly(vinyl alcohol) by $\gamma$-rays in deoxygenated aqueous solution, Radiat. Phys. Chem. 59 (2000) 91-95.

[5] C. von Sonntag, Free-Radical-Induced DNA Damage and Its Repair: A Chemical Perspective, Springer-Verlag Berlin, 2006.

[6] S. Kadlubowski, J. Grobelny, W. Olejniczak, M. Cichomski, P. Ulanski, Pulses of Fast Electrons as a Tool To Synthesize Poly(acrylic acid) Nanogels. Intramolecular Cross-Linking of Linear Polymer Chains in Additive-Free Aqueous Solution, Macromolecules 36 (2003) 2484-2492 .

[7] A. Krklješ, J. Nedeljković, Z. Kačarević-Popović, Fabrication of Ag-PVA hydrogel nanocomposite by gamma irradiation, Polym. Bull. 58 (2007) 271-279.

[8] C.L. Bell, N.A. Peppas, Biomedical membranes from hydrogels and interpolymer complexes, Adv. Polym. Sci. 122 (1995) 125-175.

[9] S. Wu, A. Sun, F. Zhai, J. Wang, W. Xu, Q. Zhang, A. Volinsky, $\mathrm{Fe}_{3} \mathrm{O}_{4}$ magnetic nanoparticles synthesis from tailings by ultrasonic chemical co-precipitation, Mater. Lett. 65 (2011) 1882-1884.

[10] P.G. Casillas, C.R. Gonzales, C.M. Perez, Infrared Spectroscopy of Functionalized Magnetic Nanoparticles, Infrared Spectroscopy-Materials Science, Engineering and Technology, InTech, Shanghai, 2012.

[11] T.H. Ngo, D.L. Tran, H.M. Do, V.H. Tran, V.H. Le, X.P. Nguyen, Facile and solvent-free routes for the synthesis of size-controllable Fe3O4 nanoparticles, Adv. Nat. Sci.: Nanosci. Nanotechnol. 1 (2010) 035001.

[12] L. Hoa, T. Dung, T. Danh, N. Duc, D. Chien, Preparation and characterization of magnetic nanoparticles coated with polyethylene glycol, Journal of Physics: Conference Series 187 (2009) 012048.

[13] T. Çaykara, i. Akçakaya, Swelling Behaviors of Ionic Poly(N,N-dimethylacrylamideco-acrylamide) Hydrogels in Various Media, J. Appl. Polym. Sci. 104 (2007) 2140$-2145$.

[14] M. Ru-yin, X. Dang-sheng, Synthesis and properties of physically crosslinked poly (vinyl alcohol) hydrogels, J. China Univ. Mining Technol. 18 (2008) 271-274.

[15] J. Jovanović, B. Adnađević, Influence of poly(acrylic acid) xerogel structure on swelling kinetics in distilled water, Polym. Bull. 58 (2007) 243-252.

[16] B. Adnađević, J. Jovanović, Novel approach in investigation of the poly(acrylic acid) hydrogel swelling kinetics in water, J. Appl. Polym. Sci. 107 (2008) 3579$-3587$.

[17] V. Kumar, C.V. Chaudhari, Y.K. Bhardwaj, N.K. Goel, S. Sabharwal, Radiation induced synthesis and swelling characterization of thermo-responsive $\mathrm{N}$-isopropylacrylamide-co-ionic hydrogels, Eur. Polym. J. 42 (2006) 235$-246$.

[18] S.Lj. Tomić, M.M. Mićić, J.M. Filipović, E.H. Suljovrujić, Swelling and drug release behavior of poly(2-hydroxyethyl methacrylate/itaconic acid) copolymeric hydrogels obtained by gamma irradiation, Radiat. Phys. Chem. 76 (2007) 801-810.

[19] Y.L. Luo, Q.B. Wei, F. Xu, Y.S. Chen, L.H. Fan, C.H. Zhang, Assembly, characterization and swelling kinetics of $\mathrm{Ag}$ nanoparticles in PDMMA-g-PVA hydrogel networks, Mater. Chem. Phys. 118 (2009) 329-336.

[20] H.K. Can, B.K. Denizli, S. Kavlak, A. Guner, Preparation and swelling studies of biocompatible hydrogel systems by using gamma radiation-induced polymerization, Radiat. Phys. Chem. 72 (2005) 483-488.

[21] I. Katime, J.L. Velada, R. Novoa, E.D. de Apodaca, Swelling kinetics of poly(acrylamide)/poly(mono-n-alkyl itaconates) hydrogels, Polym. Int. 40 (1996) 281-286.

[22] C.T. Reinhart, N.A. Peppas, Solute diffusion in swollen membranes. Part II: Influence of crosslinking on diffusive properties, J. Membrane. Sci. 18 (1984) 227-239.

[23] .N. Krklješ, M.T. Marinović-Cincović, Z.M. KačarevićPopović, J.M. Nedeljković, Dynamic thermogravimetric degradation of gamma radiolytically synthesized Ag-PVA nanocomposites, Thermochim. Acta 460 (2007) 28-34.

[24] J. Kuljanin-Jakovljević, M. Marinović-Cincović, Z. Stojanović, A. Krklješ, N.D. Abazović, M.I. Čomor, Polystyrene/hematite composites: thermal degradation kinetics, J. Compos. Mater. 45 (2010) 839-847. 


\section{IZVOD}

\section{FIZIČKO-HEMIJSKA SVOJSTVA POLI(VINIL ALCOHOL)/MAGNETIT FERROGEL KOMPOZITA UMREŽENOG GAMA ZRAČENJEM}

Milena T. Marinović-Cincović, Aleksandra N. Radosavljević, Jelena I. Krstić, Jelena P. Spasojević, Nataša M. Bibić, Miodrag N. Mitrić, Zorica M. Kačarević-Popović

Institut za nuklearne nauke "Vinča", Univerzitet u Beogradu, Beograd,Srbija

(Naučni rad)

Gelovi osetljivi na magnetno polje su nova klasa hidrogelova. Oni kombinuju magnetna svojstva magnetnih punioca sa elastičnim svojstvima gelova. Ovakvi sistemi imaju potencijalnu primenu u mekim aktuatorima, kao što su veštački mišići. S druge strane, od skora se magnetno osetljivi gelovi ispituju za hipertermijske primene. Naime, polimerne mreže imaju svojstva pogodna za primene kod kontrolisane dostave lekova, dok su magnetne čestice sa feromagnetnim i superparamagnetnim svojstvima pogodne za magnetnu hipertermiju. Cilj rada je bio sinteza magnetno osetljivih materijala, baziranih na kompozitu magnetnih čestica i hidrogela, korišćenjem gama zračenja kao agensa za umrežavanje, i ispitivanje fizičko-hemijskih karakteristika kao što su bubrenje i kinetika dehidratacije ravnotežno nabubrelog ferogela. $U$ tom cilju je korišćen poli(vinil alkohol)/magnetit ferogel ( $\mathrm{PVA} / \mathrm{Fe}_{3} \mathrm{O}_{4}$ ). PVA i $\mathrm{Fe}_{3} \mathrm{O}_{4}$ su izabrani zbog svojih biokompatibilnih svojstava. Gvožđe-oksid je hemijski stabilan, netoksičan, sa blagim magnetnim svojstvima i Kiri tačkom koja je bliska fiziološkom temperaturnom opsegu. PVA je izabran zato što je radijaciono umrežavajući polimer. Naime, radijaciono-hemijska metoda ima prednosti u odnosu na konvencionalne fizičke ili hemijske metode umrežavanja: blage reakcione uslove, zanemarljivo formiranje nusprodukata, brzo umrežavanje bez katalizatora i na kraju sterilizaciju. Gvožđe-oksid disperzija je dobijena metodom koprecipitacije $\mathrm{FeCl}_{2}$ i $\mathrm{FeCl}_{3}$ prereakcije umrežavanja. Strukturna karakterizacija sintetisanih sistema je izvrsena TEM, SEM, XRD i FTIR metodama. Iz tipičnih TEM mikrografa se može videti da čestice imaju sferičan oblik, veličine do $20 \mathrm{~nm}$. Dobijeni difraktogrami X-zračenja ukazuju da je krajnji produkt sinteze čestica smeša $\mathrm{Fe}_{3} \mathrm{O}_{4}$ i $\alpha$ - $\mathrm{Fe}_{2} \mathrm{O}_{3}$ nastala oksidacijom $\mathrm{Fe}_{3} \mathrm{O}_{4}$ tokom sinteze. Infracrveni spektri potvrđuju spinelnu strukturu $\mathrm{Fe}_{3} \mathrm{O}_{4}$ kao i kompleksnu interakciju između hidroksilnih grupa polimera na površini čestica. Studija bubrenja ukazije na porast kapaciteta bubrenja kao i kinetičkih parametara bubrenja kod PVA $/ \mathrm{Fe}_{3} \mathrm{O}_{4}$ ferogel kompozita u odnosu na PVA hidrogel. Dinamička TG analiza dehidratacije ukazuje takođe na veću brzinu dehidratacije ferogela, ali i veću energiju aktivacije dehidratacije ovih sistema. Umanjena termička stabilnost $\mathrm{PVA} / \mathrm{Fe}_{3} \mathrm{O}_{4}$ ferogel kompozita je verovatno prouzrokovana izmenjenom strukturom mreže tj. manjom gustinom umreženja.

Ključne reči: Gama zračenje • PVA hidrogel • Čestice magnetita • Ferogel • Bubrenje $\bullet$ Dehidratacija 